\title{
Cryptosporidiosis of the biliary tract mimicking pancreatic cancer in an AIDS patient
}

\author{
Criptosporidiose do trato biliar simulando câncer \\ do pâncreas em paciente com AIDS
}

\author{
Lenice do Rosário de Souza ${ }^{1}$, Maria Aparecida M. Rodrigues ${ }^{1}$, \\ José Morceli ${ }^{1}$ Raphael Kemp and Rinaldo Poncio Mendes ${ }^{1}$
}

\begin{abstract}
Diarrhea caused by Cryptosporidium sp is frequent in patients with AIDS, but involvement of other organs of the digestive tract is uncommon. We report a case of Cryptosporidium- associated obstruction of the biliary tract mimicking cancer of the head of the pancreas in a 43-year-old woman with AIDS.
\end{abstract}

Key-words: Cryptosporidiosis. AIDS. Biliary tract. Pancreatitis.

\section{RESUM0}

Adiarréia causada pelo Cryptosporidium sp é muito freqüente em pacientes com aids, mas o envolvimento de outros órgãos do aparelho digestivo é incomum. Relata-se 0 caso de uma mulher de 43 anos, que tinha aids, que apresentava obstrução das vias biliares associada ao Cryptosporidium, simulando câncer da cabeça do pâncreas.

Palavras-chaves: Criptosporidiose. AIDS. Trato biliar. Pancreatite.

Cryptosporidiosis is one of the most common human enteric infections, mainly among children ${ }^{214}$, which has been recognized after onset of the AIDS pandemic ${ }^{11}{ }^{13}$. The etiologic agent is Cryptosporidium sp, which was described in mice by Tyzzer in 190720. The firstcase of human cryptosporidiosis was reported only in 1976 in an immunocompetent patient with acute enterocolitis ${ }^{17}$.

The occurrence of asymptomatic intestinal infections caused by Cryptosporidium sp has been documented; these infections are rare in normal individuals but frequent in AIDS patients ${ }^{11}$. Disease manifestations include self-limited acute, chronic and fulminating forms. Spreading of Cryptosporidium sp leads to hepatobiliaryand respiratoryinfection, affecting the nasal and sinus mucosa ${ }^{59}$. Pitlik et $\mathrm{al}^{18}$ reported the firstcase of gallbladder infection in an AIDSpatient. There have been other reports of this complication of intestinal cryptosporidiosis in immunocompromised patients ${ }^{1317}$.

Despite being a frequent cause of morbidity, cryptosporidiosis is rarely the sole cause of death, even among AIDS patients. However, cryptosporidiosis may be the disease defining AIDS ${ }^{21}$, in these patients.
According to the AIDS Epidemiological Bulletin", cryptosporidiosis is diagnosed in $2.8 \%$ of patients aged 13 or older and in 2.7\% of individuals aged less than 13 years old. Prospective studies carried out in Brazil on patients with AIDS reported a prevalence of 12 to $20 \%{ }^{6}{ }^{8}$. However, cryptosporidiosis of the biliary tract has not been described to date.

The objective of the present study was to present the case of a patient with AIDSand biliary tractcryptosporidiosis mimicking malignant neoplasia of the head of pancreas.

\section{CASE REPORT}

A 43-year-old white female patient was admitted to the Surgical Gastroenterology Ward with a three-month history of anorexia, weakness and a weightloss of $15 \mathrm{~kg}$. Forty days after the onset of symptoms, the patient presented jaundice, fecal acholia and choluria. One month later, she started to show lower limb edema (LII), diarrhea (3-4 times/day) and abdominal pain, without any respiratory symptoms. Physical

\footnotetext{
1. Departamento de Doenças Tropicais e Diagnóstico por Imagem da Faculdade de Medicina de Botucatu da Universidade do Estado de São Paulo, Botucatu, SP. Address to: Profa Lenice do Rosário de Souza. Depto DTDI/FMB/UNESP. Distrito de Rubião Júnior s/n, 18618-000 Botucatu, SP.

Tel: 14 3811-6212, Fax: 14 3815-9898

e-mail:Isouza@fmb.unesp.br

Recebido para publicação em 10/6/2002

Aceito em 17/2/2004
} 
examination revealed regular to poor general condition, $40 \mathrm{~kg}$ of weight, skin and mucosal jaundice, whitish lesions on the palate, LUI edema, a tense abdomen with pain upon palpation in the right hypochondrium and epigastrium, and discrete hepatomegaly. Ultrasonography showed hepatomegaly with a discrete and diffuse increase in the echogenicity of the parenchyma, an enlarged head of pancreas, and dilatation of the intrahepatic bile ducts and of the common bile duct. Computed tomography (CT) of the abdomen, using oral contrast dye followed or not by intravenous injection of contrast dye, demonstrated hepatomegaly, dilatation of the intrahepatic bile ducts, common bile duct and pancreatic duct, an increased head of pancreas, discrete enlargement of the left suprarenal gland, and thickening of the rectal and sigmoid walls ( Figures 1 to 4). These results suggested neoplasia of the head of pancreas and the patient was submitted to gastroduodenopancreatectomy. During surgery, a lymph node was removed from the head region of the pancreas and histological examination of a frozen biopsy revealed, rare granulomas surrounded by fibrotic scar tissue with Paracoccidioides brasiliensis yeasts. The patient was then transferred to the Tropical Disease Ward. Since she was a woman outside the expected age range for the juvenile form of paracoccidioidomycosis ( PCM) , with poor epidemiologic

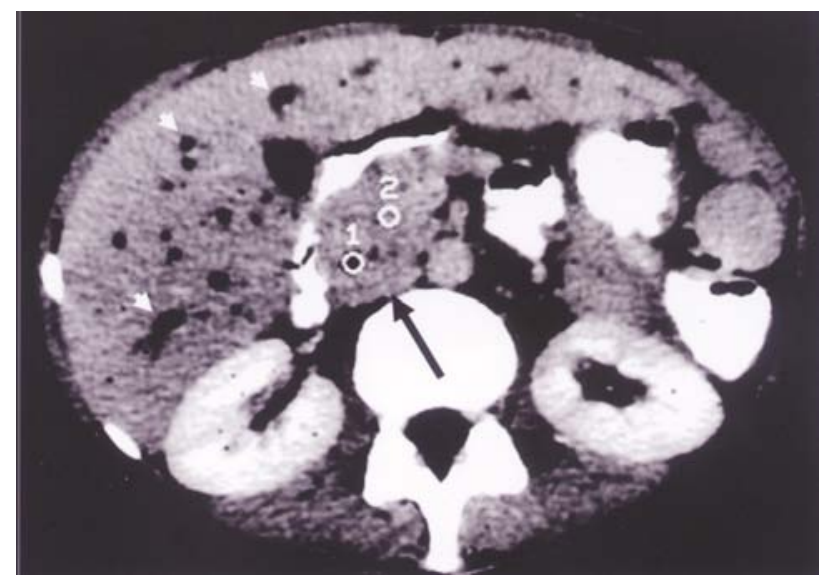

Figure 1 - Axial contrast-enhenced CT demonstrates enlargement of the pancreas head $(\rightarrow)$ and intrahepatic biliary tract dilatation $(\rightarrow)$.

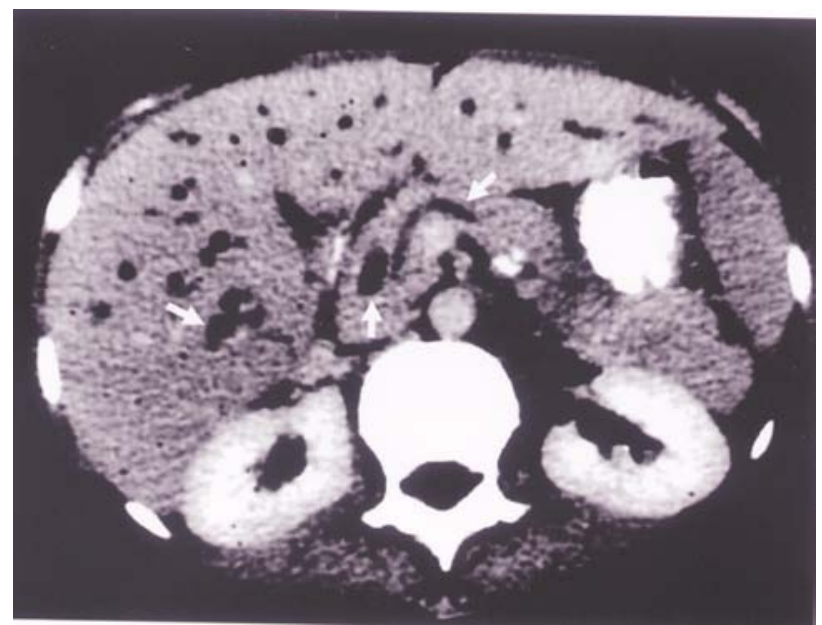

Figure 2 - Axial contrast-enhenced CT image demonstrates common bile duct, pancreatic canal and intrahepatic biliary dilatation $(\rightarrow)$. history for this mycosis, and with intense impairment of general and nutritional status, and the presence of a history favoring the possibility of HIV infection, the patient was submitted to anti-HIV antibody detection by ELISA, with a positive result. However, no anti-P. brasiliensis antibody was detected. Histological examination of the surgical specimen revealed suppurative cholangitis associated with Cryptosporidium sp infection ( Figure 5). Cryptosporidia were observed in the head of pancreas near the surface of the pancreatic duct epithelium close to the papilla. Enzymatic necrosis of the pancreatic parenchyma was absent. Although the patient did not have any respiratory complaints, a simple chest X-ray revealed discrete and diffuse linear and micronodular interstitial infiltration. The $\mathrm{CD}^{+}{ }^{+} \mathrm{T}$ cell count showed 35 cells $/ \mathrm{mm}^{3}$. Antiretroviral treatment with stavudine, lamivudine and indinavir was initiated. The patient

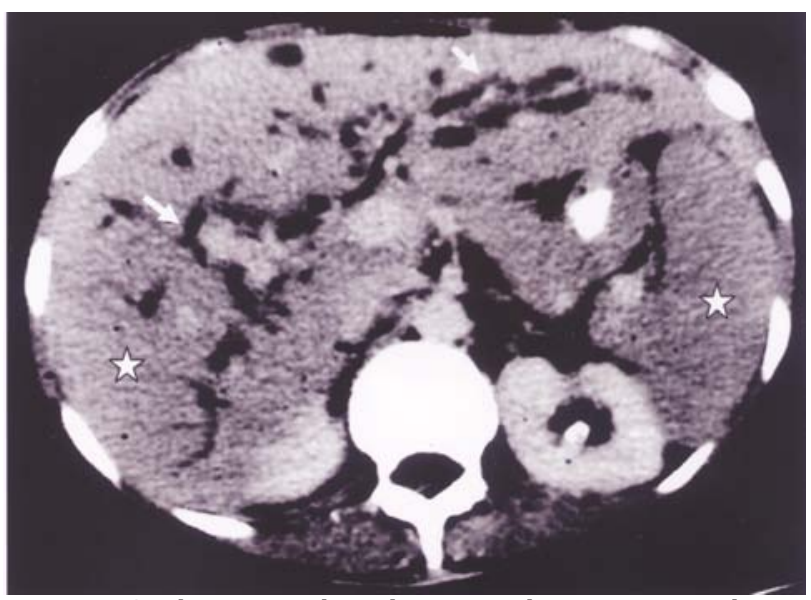

Figure 3 - Axial contrast-enhenced CT image demonstrates intrahepatic biliary tract dilatation $(\rightarrow)$ and enlarged liver and spleen (

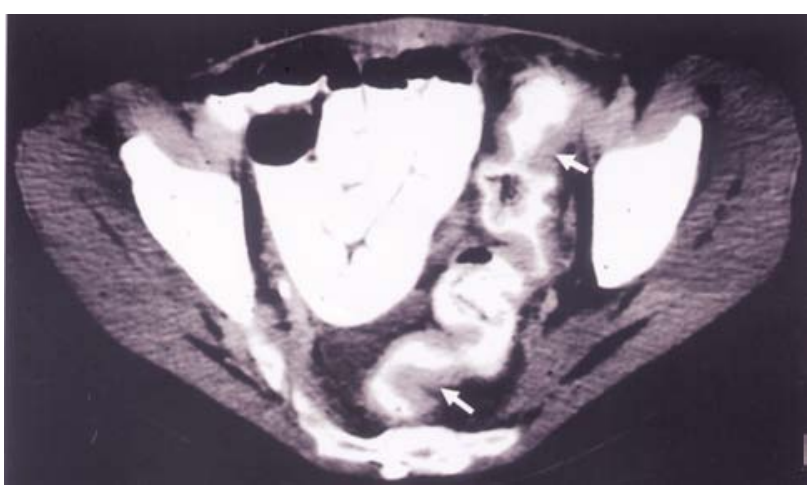

Figure 4 - Axial contrast-enhenced CT image at the level of the pelvis demonstration thick walled colon and rectum $(\rightarrow)$.

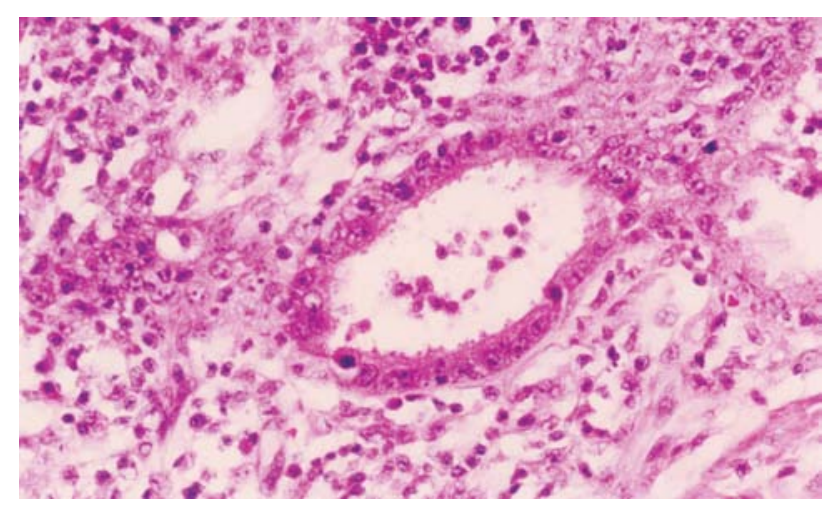

Figure 5 - Cryptosporidiosis in suppurative colangitis - Dot-like organisms on the surface epithelium (arrows) (HE 400x). 
received intravenous clarithromycin ( $1 \mathrm{~g} /$ day) and fluconazole for the treatment of cryptosporidiosis and oral candidiasis, respectively. The patient showed clinical improvement after two months and was discharged from the hospital. She did notreturn for outpatient follow-up and died at home two months later.

\section{DISCUSSION}

The present case demonstrates the difficulty in obtaining the diagnosis of pancreatic and bile duct diseases. The clinical signs and symptoms of the patient suggested neoplasia of the head of the pancreas. Although, this disease is more frequent in male patients (1.5:1) over 60 years of age, the present case was a 43-year-old woman.

The diagnosis of PCM was suggested, but this disease is much more frequentin men (10.7:1) and an age range below 30 years old is expected for the acute or subacute form ${ }^{15}$. The absence of rural working, abdominal and superficial adenomegaly, splenomegaly, and the histopathological findings of granulomas with latent yeast forms did not pointto subacute PCM diagnosis. In addition, the confirmation of the diagnosis of pancreatic and biliary tract cryptosporidiosis, which is a disease defining AIDS, indicated the need for the determination of anti-HIVantibodies that confirmed this diagnosis.

Biliarycryptosporidiosis has been observed in 15\% of the AIDS patients ${ }^{13}$. Such a localization favors the occurrence of relapses, with the biliary tract serving as a reservoir of this agent ${ }^{11}$. These patients commonlypresentchronic disease, manifesting with diarrhea, weight loss and malabsorption of nutrients, water-soluble vitamins, D-xylose and fat ${ }^{1117}$. In the presentstudy, the patient did not present chronic diarrhea as usuallyreported ${ }^{1116}$, butshowed biliary tract involvement and intense weightloss.

Biliary involvement by Cryptosporidium seems to be related to a more advanced stage of the disease and a low $\mathrm{CD} 4^{+} \mathrm{T}$ lymphocyte count, especially when it falls below 50 cells $/ \mathrm{mm}^{3}$, with a higher risk of death due to cryptosporidiosis ${ }^{21}$. Our patient had a $\mathrm{CD}^{+}{ }^{+} \mathrm{T}$ lymphocyte count of $35 \mathrm{cells} / \mathrm{mm}^{3}$, a twomonth hospital stay and died two months after discharge.

Clinical manifestations of cryptosporidiosis can be misdiagnosed, and in AIDS patients it can mimic sclerosing cholangitis, cholecystitis and pancreatitis ${ }^{16}$. In AIDS patients, stone-free cholecystitis and thickening of the gallbladder are mainly caused by Cryptosporidium sp and cytomegalovirus ${ }^{1}$.

Imaging findings are nonspecific. Hashmey et a ${ }^{12}$ performed 38 diagnostic imaging studies on 20 cryptosporidiosis patients. Ultrasonography detected thickening of the gallbladder wall in five out of 10 patients, biliary sludge in two, dilatation of the bile duct in two, and calculi in one. Computed tomography scan revealed dilatation of the bile ducts in 3 out of 4 patients. Endoscopicretrograde cholangiopancreatography (ERCP) detected Cryptosporidium sp 0ocysts in material obtained by brushing and/or biopsy of the bile ducts in three patients. Narrowing of Vater's ampulla and alternating narrowing and dilatation of the intrahepatic bile ducts could also be observed by this method. These authors considered Cryptosporidium sp to be the primary cause of cholecystitis in AIDSpatients.
In our case, abdominal CT scan and ultrasonography showed alterations suggestive of sclerosing cholangitis, such as dilatation of both common and intrahepatic bile ducts. Enlargement of the head of the pancreas was also observed, suggesting neoplasia.

Autopsy studies ${ }^{10}$ have shown the presence of Cryptosporidium sp inside the pancreatic duct, with evidence of periductal inflammation. In the present case, histological examination demonstrated Cryptosporidium sp near the surface of the pancreatic duct epithelium close to the papilla, in addition to lymphoplasmocytic inflammation, a fact that might explain the enlargement of the head of the pancreas as detected by ultrasonography, CT scan and during surgery. Goodwin ${ }^{10}$ reported the occurrence of pancreatic disease with periductal inflammation and interstitial edema in five cases, generally observed in the head region of the pancreas, without histopathological evidence of pancreatitis. Our patient did not present enzymatic necrosis of the pancreatic parenchyma, which is fundamental for the diagnosis of pancreatitis.

In the present study, a chest plain film showed mild and diffuse linear and micronodular interstitial infiltration of the lungs. Although some authors ${ }^{37}$ have suggested pulmonary involvement by Cryptosporidium sp, more frequent etiologies such as Pneumocystis carinii cannot be excluded.

Diagnostic confirmation of extraintestinal cryptosporidiosis is difficult. Vakil et al. ${ }^{21}$ established the diagnosis in 9 (38\%) patients with biliary symptoms by demonstrating Cryptosporidium sp in the biliary tract through the analysis of biliary brushings obtained by endoscopy and histological examination of gallbladder material obtained by biopsy. In our study, the diagnosis of cryptosporidiosis was confirmed by histological examination of the surgical specimen.

Treatment of cryptosporidiosis is difficult, and variable degrees of efficacy were observed with macrolides, paromomycin and sulfonamides ${ }^{11} 1921$. Our patient showed an excellent response to clarithromycin maintained for 38 days.

Sphincterotomy has been reported to provide a rapid result and substantial relief of pain in the right hypochondrium in most AIDSpatients with biliary cryptosporidiosis ${ }^{1}$. Endoscopic papillotomy and cholecystectomy have also been used with favorable results ${ }^{21}$. In the present study, the probably overly extensive surgery, led to the removal of the distal obstacle of the common bile duct, with a similar effect to that obtained with papillotomy and sphincterotomy.

Our experience with the case presented herein leads us to consider the extraintestinal cryptosporidiosis in AIDS patients with biliary tract involvement.

\section{REFERENCES}

1. Benhamou Y, Caumes E, Gerosa Y, Cadranel JF, Dohin E, Katlama C, Amouyal P, Canard JM, Azar N, Hoang C, Charpentier YL, Gentilini M, Opolon P, Valla D. AIDS-related cholangiopathy. Critical analysis of a prospective series of 26 patients. Digestive Diseases Sciences 38: 1113-1118, 1993.

2. Bezerra FSM, Troiani RM, Parente TML, Paiva ARA, Queiroz RMP, Coelho JR, Oliveira MF. Incidência de criptosporidiose em crianças com desnutrição de moderada à grave internas no IPREDE (Instituto de Prevenção à 
Desnutrição e à Excepcionalidade) em Fortaleza-CE. Revista da Sociedade Brasileira de Medicina Tropical 34( supl I) : 300, 2001.

3. Brady EM, Margolis ML, Korzeniowski OM. Pulmonary cryptosporidiosis in acquired immune deficiency syndrome. Journal of American Association 252: 89-90, 1984.

4. Coordenação Nacional de DST/AIDS. Boletim Epidemiológico, Ministério da Saúde, Brasília 1: 48-49, 2000.

5. Davis JJ, Heyman MB. Cryptosporidiosis and sinusitis in an immunodeficient adolescent. The Journal of Infectious Diseases 158: 649, 1988.

6. Dias RMDS, Mangini ACS, Torres DMAGV, Corrêa MOA, Luptti N, Corrêa FMA, Chieffi PP. Cryptosporidiosis among patients with acquired immunodeficiency syndrome (AIDS) in the county of São Paulo, Brasil. Revista do Instituto de Medicina Tropical de São Paulo 30: 310-312, 1988.

7. Dupont C, Bougnoux ME, Turner L, Rouveix E, Dorra M. Microbiological findings about pulmonary cryptosporidiosis in two AIDS patients. Journal of Clinical Microbiology 34: 227-229, 1996.

8. Garlipp CR, Bottini PV, Teixeira ATLS. The relevance of laboratory diagnosis of human cryptosporidiosis and other coccidia. Revista do Instituto de Medicina Tropical de São Paulo 37: 467-469, 1995.

9. Giang TT, Pollack G, Kotler DP. Cryptosporidiosis of the nasal mucosa in a patient with AIDS. AIDS 8: 555-565, 1994.

10. Goodwin TA. Cryptosporidiosis in the acquired immunodeficiency syndrome. A study of 15 autopsy cases. Human Pathology 22: 1215-1224, 1991.

11. Griffiths JK. Human cryptosporidiosis: epidemiology, transmission, clinical disease, treatment, and diagnosis. Advances in Parasitology 40: 37-85, 1998.

12. Hashmey R, Smith NH, Cron S, Graviss EA, Chappell CL, White Jr AC. Cryptosporidiosis in Houston, Texas. A report of 95 cases. Medicine 76: 118-139, 1997
13. Labarca JL, Tagle VR, Acuña GL, Oddó DB, Pérez CC, Guzman SB. Colecistitis aguda alitiasica por Cryptosporidium en un paciente con SIDA. Revista Médica de Chile 120: 789-793, 1992.

14. Machado-Silva JR, Silva S, Silva SP, Gouveia YS, Silva NO, Mello MERM, Moura H, Bello AR. Pesquisa de coccídeos intestinais em crianças abaixo de 10 anos com diarréia na cidade do Rio de Janeiro. Revista da Sociedade Brasileira de Medicina Tropical 34( supl I) : 311, 2001.

15. Marques SA, Franco MF, Mendes RP, Silva NCA, Baccili C, Curcelli ED, Feracin ACM, Oliveira CS, Tagliarini JV, Dilon NL. Aspectos epidemiológicos da paracoccidioidomicose na área endêmica de Botucatu ( São Paulo - Brasil). Revista do Instituto de Medicina Tropical de São Paulo 25: 87-92, 1983.

16. McGowan I, Hawkins AS, Weller IVD. The natural history of cryptosporidial diarrhea in HIV-infected patients. AIDS 7: 349-354, 1993.

17. Nime FA, Burek JD, Page DL, Holcher MA, Yardley JH. Acute enterocolitis in a human being infected with the protozoan Cryptosporidium. Gastroenterology 70: 592-598, 1976.

18. Pitlik SD, Fainsteim V, Rios A0. Cryptosporidial cholecystitis. The New England Journal Medicine 308: 967-970, 1983.

19. RehgJE. A comparison of anticryptosporidial activity of paromomycin with that of other aminoglycosides and azithromycin in immunosuppressed rats. Journal of Infectious Diseases 170: 934-938, 1994.

20. Tyzzer E. A sporozoan found in the peptic glands of the common mouse. Proceedings of the Society for Experimental and Medicine 5: 12-13, 1907.

21. Vakil NB, Schwartz SM, Buggy BP, Brummitt CF, Kherellah M, Letzer DM, Gilson IH, Jones PG. Biliary cryptosporidiosis in HIV-infected people after the waterborne outbreak of cryptosporidiosis in Milwaukee. The New England Journal Medicine 334: 19-23, 1996. 